\title{
Body Image Esteem and Photo Manipulation Among Social Media Users
}

\author{
Hai Chung Pham ${ }^{1}$ (D), Lien Nguyen ${ }^{2}$, Tuan Anh Vu ${ }^{3}$, Phuong Tran ${ }^{2}$ \\ ${ }^{1}$ School of Journalism and Communication, University of Social Sciences and Humanities, Vietnam National University, Hanoi, 336 Nguyen \\ Trai Str., Hanoi, Vietnam \\ ${ }^{2}$ Hanoi University, Km9, Nguyen Trai Road, Thanh Xuan District, Hanoi, Vietnam \\ ${ }^{3}$ University of Technology Sydney, 15 Broadway Ultimo, Broadway NSW 2007, Australia \\ Corresponding author: Hai Chung Pham (phamhaichung@gmail.com)
}

\begin{abstract}
When interacting with each other virtually on social media sites, users may potentially encounter their own "self-presence". To improve their physical self-presence on social media, users might resolve to curate themselves to match their ideal perceptions of themselves and others. This study examines the intention to alter one's factual self in real life whilst contemplating the on-line self on social media. Data were derived from a social survey of Vietnamese adults. The results indicate the remarkable mediating relationship from the level of editing self-images to three choices of intention to change the body image in real life. Nevertheless, this paper does not provide enough evidence to confirm any link connecting distal intentions (D-intentions), proximal intentions (P-intentions) and motor intentions (M-intentions) with private self-consciousness, with the latter as the moderator variable. This study, therefore, might provide an exclusive idea of how online behaviour can be related to one's offline behaviour in terms of body image. With an understanding of this aspect, many implications can be found in regard to applications/programmes in research, development and marketing.
\end{abstract}

\section{Keywords}

Photo manipulation; Social media; Human-internet interaction; Body image. 


\section{Introduction}

Social media users may construct their "self-representation" via interactions on social networking sites. Stated by Tamborini and Skalski in their research conducted in 2006, "self-presence" signifies the state formed through a chain of reactions from feeling a sense of affinity between one's online and offline self to raising awareness of oneself in the virtual world. It has been advocated by many studies that social media could be considered an "identity performance" (Thumim, 2012; Ellison and Boyd, 2007; Westlake, 2008). Rooted in Erving Goffman's paper (1959), the notion of "the presentation of self in everyday life" is suggested to be crucial to explaining processes of identity construction. Through a combination of visual and textual content that is carefully selected and published on social media platforms, one feeds their target audience (mostly peers) their curated identity and life story (Boyd and Ellison, 2007).

Tamborini and Skalski (2006) divided self-presence activities into two types: (1) self-presence in connection with offline context; and (2) self-presence in disconnection with offline context. An example for this is the experiment conducted by Vasalou and Joinson (2009), in which each participant was asked to design their own personal avatar for three networking platforms. Study findings from this experiment shed some light on the orientation towards creating something that consistently reflected their offline identity despite the varying online context (gaming, dating, blogging, etc.). The same idea could also be found in other studies of Baym (1998), Elias and Lemish (2009), Grisso and Weiss (2005), Herring et al. (2004), and Vasalou and Joinson (2009), which establish a connection between online and offline selfinvolving virtual replication of racial and sexual dynamics.

In some cases, online identities are so rooted in offline contexts that they require knowledge of those contexts in order to be elucidated. One example of that is the research by Boyd in 2010, which explained "social steganography" - a term that signifies the state of hiding in public on social network platforms such as Facebook. Boyd described that youngsters tend to compose and publish online content (abbreviations, song lyrics, etc.) that only the poster's friends and acquaintances are able to fathom and interpret its peculiar meaning. Outsiders such as parents might understand that same piece of content in a completely different way that results in a deviation from its true meaning. These examples demonstrate a much higher level of dependency of virtual identities on offline ones.

The connection of self-presence and its role in physical health, appearance and contentment was also found by Behm-Morawitz in 2013, such that self-presence indicates the online avatar has an outstanding impact on physical health together with appearance, while it is also positively correlated with fulfilment in virtual relationships. It is believed that while online self-presence influences the physical and mental health of online world participants, one's willpower to join that online world also has an impact on the level of avatar influence within that virtual environment. All these findings were reported in an experiment with participation of Second Life (SL) players in which each of them would complete an online questionnaire. Its main focus was to explore the reason driving them to join the online world, their experiences when being in Second Life, amour-propre, body esteem, self-awareness effect of the avatar on physical and mental health, well-being, appearance and the gratification with their relationships in Second Life.

In research about Vietnamese women and self-presence, among people who participated, a concurrent impact was found between self-expression and Confucian values, socialist ideology and international neoliberalism. The convergence of these factors has altered what people expect in one gender and how these genders interact with each other and, in turn, affect their expression creation and display on Facebook (Nguyen et al., 2020).

In an analysis by Bullingham and Vasconcelos (2013), the virtual identity and interacting practices of 10 bloggers and SL users in their habitat were studied regarding their expressions given the presence of retouching as a minor form to acquire persona, dividing the self, adaptation process, and masking, 
anonymizing and pseudonymization. The primary takeaway of the research was that, rather than adopting a whole persona, participants were interested in virtualizing their offline identity, but they engaged in morphing bits of self. This finding reinforces the main premise of Goffman's study that, when on the "front stage", people deliberately choose to present a given identity. Goffman's original framework has proven to be of great use as an explanatory framework to understanding identity via the interaction and the presentation of self in the virtual environment.

There are binaries between social media and the offline world in many respects and social media representation confounds the concepts of greater freedom, authenticity and empowerment (Dobson, 2016). People using social network sites (SNS) yearn to look forward to a true, natural image, but at the same time, technological advances have made it easier than ever to erase the line between virtuality and reality. McLean et al. (2015) note the "investment and effort participants expend choosing photos of themselves to share on social media and concern they have about such posts." (p. 1134) Whenever posting photos on social media platforms, users might have carried out online image surgery in various ways. Touch-up tools make it easy for anyone to reshape and level up their images exactly as they wish.

When editing photos, social media users commonly give themselves similar enhancements - bigger eyes, sharper chin, brighter skin. People, especially younger ones, have a common unrealistic beauty standard and try to make themselves become like that (Lowe-Calverley and Grieve, 2018). Photos are mainly treated with filters (McLean et al., 2015), accompanied by social networking applications such as Instagram, Snapchat, etc., or external support applications. Many applications allow changing skin colour, removing moles, chin pulling, eye enlargement, breast augmentation and leg lengthening.

Online image surgery is expected to result in a negative image of and anxiety towards one's own body. Motivation for image taking and posting is triggered by body objectification. Personal visual presentation is a representation of self and a requirement for social media profiles to build social interaction (Hill et al., 2021). Even though text writing is possible, photo sharing is the main approach to identity disclosure on social media (McLean et al., 2015). As individuals curate their best self-image, they conform to social ideals of body image (thin, attractive and fit) (Shukla, 2017).

It is suggested that editing/manipulating behaviour is connected with body discontent and self-objection (Lamp et al., 2019; Lonergan et al., 2019; McLean et al., 2015; Cohen et al., 2018). These studies provoke the idea that people "fix" their flaws to conform to the ideal self that they want to be when presenting themselves online. Behm-Morawitz (2013) concluded that "the avatar may serve as a source of motivation or inspiration to take better care of the body offline", indicating the possible effect of virtual life on real life. Among photo uploaders, those who edit their self-image are often found to internalize the idealized body more (Behm-Morawitz, 2013).

McLean et al. (2015) suggested that although there was little evidence confirming the existence of a positive relationship between media exposure and body-related eating disorders. Users do not want to be left behind or look worse. Thus, if someone uses a filter to correct an image, making themselves look like a supermodel, others will want to copy that effect. People who are "inferior in appearance", often obsessed with what they consider to be defects or flaws in their bodies, are therefore easily able to try and find ways to look like their edited image permanently. These feelings motivate people to choose to post their own best photos where they "decorate" their appearance with apps. McLean et al. (2015) and Cohen et al. (2018) discovered that the more people invest in their photos and wanted them to be picture-perfect (by performing photo manipulation), the more they are likely to have higher levels of body dissatisfaction and eating disorders. However, there was a difference between these two in the satisfaction gained through selfie-posting activity, with only Cohen et al. (2018) confirming this facet in their study. In addition to body malcontentment, there are numerous elements implying a positive relationship between content posted on social media and the traits these posts' owners might possess. 
Beauty norms and social comparisons are the two main factors that influence the inculcation of how a body is considered to be idealistic, where one compares who is perceived as similar to oneself (Fardouly et al., 2015; Sunden, 2003). This is a frequent, unintentional and automatic process. Internalization of beauty ideals and comparisons focused on looks contribute to body discontentment (Thompson et al., 1999). The same societal comparison exists across genders and age categories while showing no difference between social media and conventional media. However, research findings indicate that social network sites could have a greater detrimental effect on people than conventional media might ever do (e.g., Tiggermann and Miller, 2010; Tiggermann and Slater, 2013). On social media, where peer-to-peer connection is speedy and at ease, the comparison opportunity increases and so is more readily available (Tiggermann and Miller, 2010). The time spent engaging with photo activities of self and others is directly related to body concern (Meier and Gray, 2014) and worse for individuals who are "public conscious" (such as those who care about others' comments on their photos or actively manage their tagged photos). Beauty norms shared by peers also pressure young girls into constant body surveillance and flaw awareness (Wertheim and Paxton, 2012; Mills et al., 2018). This suggests that one is not only objectified by others but also engages in self-objectification. While self-images are frequently linked to selfish and narcissistic individuals (Fox and Rooney, 2015; Krizan and Bushman, 2011), research has indicated that comparing the self-image with others leads to an adverse effect on body esteem (Lee, 2020).

Chae (2017) concluded that when one compares themselves with peers, it might result in higher editing of one's own photos. Another finding derived from a study conducted by Fox and Vendemia (2016) was that women who compared themselves to others were more likely to experience anxiety towards their bodies. Those findings indeed shed some light on the idea that photo-editing behaviours might be a trait of individuals who are more likely to be affected by surrounding people. In fact, people may feel that they are not impressive enough if they are not like the influencers they follow. In the USA, this phenomenon is even called "Snapchat dysmorphia". In other countries, it may be Instagram syndrome or Facebook syndrome. Doctors and researchers describe it as a form of "body dysmorphic disorder" (BDD).

With a higher frequency of selfie taking, one may build an idealized virtual self-image that is increasingly divergent from one's actual self (Halpern et al., 2017). Once the individual manipulates their online image, self-image discrepancy enlarges (Chae, 2017). If viewers perceive their peers' image is modified, they judge the individuals' personal quality and image-related behaviour more harshly (Vendemia and DeAndrea, 2018). Therefore, one who validates their social standing on social media may end up more immersed in the virtual self or seek real-world intervention to close this gap (Halpern et al., 2017).

The concept of converting purposes into real actions is the ultimate focus of this research paper. There are many research papers carrying the same mission of exploring what drives human behaviours, namely the theory of reasoned action (TRA) by Fishbein and Ajzen (1980), the theory of planned behaviour (TPB) by Ajzen (2011), the protection motivation theory (PMT; Maddux, 1993; Maddux and Rogers, 1983), the model of behavioural self-regulation (Scheier and Carver, 1988), and the intentionality of intention and action (Searle, 1981).

Numerous studies have one thing in common, which is the agreement of the crucial role that behavioural intentions hold as a predictor of action being taken. Bearing that in mind, a considerable number of studies have checked the prior statement in their research. A significant number of research papers on exercising have adopted the theory of planned behaviour in their meta-analysis. All of them have shown that the relationship is of substance, in which $r=0.48$ (McEachan et al., 2011), implying a medium-sized range of the influence (Ferguson, 2009). Nevertheless, $77 \%$ of the variation in behaviour, which is more significant when attempting to understand what drives human behaviour, and its function in modifying behaviour (Rhodes and DeBruijin 2013) is still undefined. The connection therefore dips to $r=0.22$ when examining the changes in physical activity. 
Taking into consideration that this study concentrates on one's intention to change their physical appearance with different measures, exercising being one of them, we also search for other studies in health behaviour domains. With an analogous result, by applying TPB to physical activity after cardiovascular disease recovery, it was suggested that only 23\% of the variance between 6 and 10 weeks following the rehabilitative treatment was explained by intention. Taking these findings into consideration, it is believed that intention might not be the main factor driving human action. It is nonetheless indicated that practically no physical activity is taken without intent in the dichotomization of the intent and physical activity link around the standards for healthcare (Rhodes and DeBruijin, 2013). This suggests that intention remains necessary in one's action process, but not adequate to comprehend numerous people's exercise motives due to the existence of intention-behaviour discordance, which is often indicated as the gap between intention and behaviour (Sheeran, 2002; Sniehotta et al., 2005).

There exists a considerable body of literature on the intention-behaviour gap in which conceptual and empirical analyses reveal that those who fall into the gap are individuals who have intentions to carry out but fail to realize the factors that drive them to do so (Orbell and Sheeran, 1998; Sheeran, 2002).

This finding implies that intentions are not solely responsible for actions being taken. Indeed, before conducting any action, one has to discern the reason behind the formation of intention. To better understand what causes behaviour alteration, more profound examination and investigation needs to be made regarding posting on purpose to get predefined desired results (Abraham et al., 1998). Being conscious of the mentioned aspect, later studies on implementation intentions and attention control (Kuhl and Fuhrmann, 1998; Milne et al., 2002; Orbell, 2003; Orbell et al., 1997; Orbell and Sheeran, 1998) added the volitional construct to motivational prediction models, for instance TPB, TRA and PMT or other suggestions such as changed model phases (e.g., the transtheoretical model by Prochaska and DiClemente, 1983).

It is implied that there are motivational and volitional functions in the process from intention to action, in which the motivation serves first as a providing source of outcome expectancy, self-beliefs, perceived selfefficacy and risk perceptions, followed by a volitional phase when the desired actions are planned beforehand, inaugurated and preserved, while recurrence has to be controlled (Sniehotta et al., 2005). Nonetheless, there are still some problems with this approach. For example, when taking action, one has to divide one big objective into numerous tasks holding different outcome expectancies, risk perceptions, etc. Therefore, it is not completely accurate when viewing the intention process as distinct step-by-step stages.

With similar ideas but different views, recent research in neuroscience has approached the reason behind human behaviours in two ways: cognitive and volitional. In terms of the volitional approach, Russian psychologist Aleksey Leontiev augmented ideas from prior studies to form a pertinent way of thinking, in which to understand actions one needs to get the idea of the general agency of the subject. The agency includes the subject, object, activity and the artifact. They are related to each other in a way that by committing the activity, the subject fulfils its goal on a particular motive, while physical and social instruments consistently mediate it. There are levels in the analysis in which activity is considered the first level and is driven by motive, while being peculiarized by its objective. This activity, therefore, breaks down into actions which have corresponding goals and sub-actions being the operation role (Leontiev, 1981; Leontiev, 1978). For example, the activity "change my appearance in accordance with how I edited my pictures posted on Facebook" has an objective such as "to be confident in real life", a motive of "selfactualization" and would be translated into numerous actions such as "put on makeup", "go to the gym", etc.

In regard to the cognitive approach, Pacherie (2006) presents distal intentions (D-intentions), proximal intentions (P-intentions) and motor intentions (M-intentions) as the three forms of intentions. The Dintentions inspire practical thinking about how to achieve the desired outcome, including tools and 
schemes, which corresponds to the role of the objective in the volition approach and motivation in other studies. Meanwhile, the P-intentions serve in the present as a form of monitoring. They guarantee that envisaged behaviour becomes actual through situational monitoring of their unfolding. The last type of intention, the M-intention, takes care of unconscious movements during the operation. It can be seen that even following different paths, the two approaches work based on the same set of thoughts and actions and fulfil the post-intentional gap other studies mentioned while strengthening the route from intention to real action.

A large number of existing studies in the broader literature have examined this behaviour in relation to body dissatisfaction and found out that the act of photo investment including taking and editing selfphotos is related to higher degrees of eating disorders and body discontentment (McLean, 2015; Lonergan, 2019; Meier and Gray, 2014). Nevertheless, this relationship has not yet found a common voice on whether body dissatisfaction is the causal determinant of editing behaviour. There are research papers that indicate people who are not content with their look are likely to modify their pictures and invest their time in selecting the best ones to post on social network platforms (Cohen et al., 2018; Fox and Rooney, 2015).

Some studies suggest that those who are dissatisfied with their appearance are inclined to manipulate their pictures in an online environment, such as digital editing and selecting the "perfect" selfie to be published on social media (Cohen et al., 2018; Fox and Rooney, 2015). Meanwhile, when studying the same phenomenon, some authors believe that the act of editing self-photos does not result from body dissatisfaction but other reasons, for instance social comparison, so that when they are exposed to altered pictures, they want to look better or at least like others; this triggers the will to change their appearance (Chae, 2017). Other research papers pertaining to this matter also suggest strongly that the relationship is actually circular, in which people who do not like their appearance would take action in editing "selfies", then experience a self-reflection process in which they might have feelings of anxiety, self-scrutiny, depression, body concerns and insecurities after realizing that these photos are disingenuous (McLean, 2015; Lamp et al., 2019). These mental phenomena are likely to affect the body esteem and can be interpreted in the way that when one cultivates their self-photos and realizes the discrepancy between the ideal appearance and actual appearance, they would experience low body esteem.

This article is divided into four major sections. First and foremost, the introduction is in charge of delivering an overview and numerous essential points of the study, followed by a literature review, raising a spectrum of views from scholars on the subject. After that, the method section is dedicated to explaining how the research has been carried out, including information in terms of hypotheses, variables and methodology of running the tests. In the third section, the results derived from the tests are examined, which facilitates drawing findings for the main research question stated at the beginning of the research. Last but not least, the limitations and conclusion of the paper are discussed in the last section so that readers can comprehend the scenarios of the study and interpret them accurately.

\section{Research Methods}

\subsection{Hypotheses}

With the relationship between intention and action outlined, we hypothesized that individuals manipulating their self-image pictures when realizing their own three layers of intentions might take action in real life. The hypotheses are as follows:

H1: Body image esteem is positively related to perceived importance of self-photo manipulation.

H2: Body image esteem is positively related to extent of self-photo manipulation.

H3: Body image esteem is negatively related to frequency of self-photo manipulation. 
H4: Perceived importance of self-photo manipulation is positively related to extent of self-photo manipulation.

H5: Perceived importance of self-photo manipulation is positively related to frequency of selfphoto manipulation.

H6: Private self-consciousness is positively related to extent of self-photo manipulation.

H7: Private self-consciousness is positively related to frequency of self-photo manipulation.

H8: Private self-consciousness is positively related to perceived importance of self-photo manipulation.

H9: Public self-consciousness is positively related to extent of self-photo manipulation.

H10: Public self-consciousness is positively related to frequency of perceived importance of selfphoto manipulation.

H11: Public self-consciousness is positively related to perceived importance of self-photo manipulation.

H12: Social anxiety is positively related to extent of self-photo manipulation.

H13: Social anxiety is positively related to frequency of self-photo manipulation.

H14: Social anxiety is positively related to perceived importance of self-photo manipulation.

\subsection{Procedure and participants}

In order to test these hypotheses, a survey was conducted with 1204 young Vietnamese. Individuals were recruited through an online survey in Vietnam. We excluded four participants who completed $<80 \%$ of questionnaire items or who reported never using Facebook $(\mathrm{N}=4,0.33 \%)$, leaving the final data set of 1204 individuals $($ Female $=876$, Male $=310$, Other $=18)$. Ages ranged from 18 to 22 years $($ Male $=231$, Female $=724$, Other $=15)$ and 23 to 30 years old $($ Male $=79$, Female $=152$, Other $=3)$, see Table 1 .

Table 1. Respondent profile.

\begin{tabular}{|l|l|l|l|}
\hline Profile (N=1204) & Characteristic & Frequency & $\mathbf{\%}$ \\
\hline \multirow{4}{*}{ Gender } & Female & 876 & 72.8 \\
\cline { 2 - 4 } & Male & 310 & 25.7 \\
\cline { 2 - 4 } & Other & 18 & 1.5 \\
\hline \multirow{2}{*}{ Age } & $18-22$ years old & 970 & 80.6 \\
\cline { 2 - 4 } & $23-30$ years old & 234 & 19.4 \\
\hline \multirow{2}{*}{$\begin{array}{l}\text { Hours per day } \\
\text { spent using } \\
\text { Facebook }\end{array}$} & $<1$ hour & 90 & 7.5 \\
\cline { 2 - 4 } & $1-3$ hours & 609 & 50.6 \\
\cline { 2 - 4 } & $>3$ hours & 505 & 41.9 \\
\hline
\end{tabular}

\subsection{Measures}

\subsubsection{Photo manipulation and investment}

To quantify levels of self-image editing on Facebook, the self-photo manipulation scale was used (McLean et al., 2015). This 5-point Likert scale ( 1 =never; $5=$ always) was modified in order to cover more common and up-to-date types of editing features. These items assessed the extent to which participants digitally edited selfies (level of commitment to online surgery). Scores ranged from 10 to 50, higher scores 
suggesting greater manipulation of the images. The overall score was determined from the average of all items, varying from 0 to 10, with higher scores indicating greater investment in images. The composite reliability is 0.898 .

\subsubsection{Body esteem}

Body esteem was assessed using the 5 items of the body esteem scale (BES) (Mendelson et al., 2001). The level of concern was measured by two items: "I am preoccupied with trying to change my body weight", "Weighing myself depresses me". Appearance was assessed by three items: "I wish I looked like someone else", "There are lots of things I'd change about my looks if I could", "My looks upset me". All items were set on a 5 -point Likert scale ( 1 = never; 5 =always). A higher total score on all items indicates lower body esteem and vice versa. The composite reliability is 0.869 .

\subsubsection{Private and public self-consciousness}

Public and private self-consciousness were measured using the revised self-consciousness scale for a general population developed by Scheier and Carver (1985). In the current study, the full scale of 7 items was used to estimate private self-consciousness and 6 items to measure public self-consciousness. Participants rated their agreement with the statements on a 5-point Likert scale $(1=$ totally disagree; $5=$ totally agree). The scores were averaged across all items. The composite reliability was 0.905 for private self-consciousness and 0.869 for public self-consciousness.

\subsubsection{Social anxiety}

The revised self-consciousness scale for general population developed by Scheier and Carver (1985) was used to assess the self-reported social anxiety. Higher scores indicate greater social anxiety. The composite reliability is 0.876 .

\section{Results}

\subsection{Measurement model}

The study employed a PLS algorithm to test CFA loadings and examined the reflectiveness of measurement items with composite reliability (CR), Cronbach's alpha and average variance extract (AVE) as shown in Table 2. Eight items, namely EST1, EST4, EST5, EST9, PRI3, PRI8, SOC4 and EDIT2, were eliminated for their outer loading not meeting the minimum threshold of 0.6 (Stevens, 2002). For construct validity, the study followed the recommendation of Hair et al. (2017) with CR, Cronbach's alpha and AVE above 0.7, 0.7 and 0.5 respectively. Therefore, three more items (EDIT9, EDIT10, and PUB7) with the lowest loading were dropped subsequently to keep the AVE range from 0.507 to 1.

Table 2. Summary of variables measured in this study.

\begin{tabular}{|l|l|l|}
\hline Variable & Code & Items \\
\hline $\begin{array}{l}\text { Perceived importance of } \\
\text { self-photo manipulation }\end{array}$ & EDIT_IMP & The importance of photo editing to you? \\
\hline Frequency of editing photos & EDIT1 & I have edited my photos before posting on Facebook. \\
\cline { 2 - 3 } & EDIT3 & I have edited it to make my skin look smoother. \\
\cline { 2 - 3 } & EDIT4 & I have adjusted my skin colour. \\
\cline { 2 - 3 } & EDIT5 & $\begin{array}{l}\text { I have modified pictures so that my body on Facebook looks } \\
\text { slimmer/fatter/more muscular than in real life. }\end{array}$ \\
\cline { 2 - 3 } &
\end{tabular}




\begin{tabular}{|c|c|c|}
\hline Variable & Code & Items \\
\hline & EDIT6 & $\begin{array}{l}\text { I have modified the facial features (eyes, nose, jaw, etc.) to } \\
\text { make the photos look better. }\end{array}$ \\
\hline & EDIT7 & $\begin{array}{l}\text { I have removed features I don't want on my photos (acne, } \\
\text { moles, wrinkles, birthmarks, scars, etc.). }\end{array}$ \\
\hline & EDIT8 & $\begin{array}{l}\text { I have edited my body parts (legs, arms, stomach, etc.) to make } \\
\text { the photos look better. }\end{array}$ \\
\hline \multirow[t]{5}{*}{ Body image esteem } & EST2 & I am preoccupied with trying to change my body weight. \\
\hline & EST3 & Weighing myself depresses me. \\
\hline & EST6 & I wish I looked better. \\
\hline & EST7 & There are lots of things I'd change about my looks if I could. \\
\hline & EST8 & My looks upset me. \\
\hline \multirow{6}{*}{$\begin{array}{l}\text { Private self-consciousness } \\
\text { (PRI) }\end{array}$} & PRI1 & I always try to understand myself. \\
\hline & PRI2 & I have never contemplated myself. \\
\hline & PRI4 & I often pay attention to my inner feelings. \\
\hline & PRI5 & I often reflect on why I do this and that. \\
\hline & PRI6 & I sometimes slow down to look at myself. \\
\hline & PRI7 & I am acutely aware of the change in my emotions. \\
\hline \multirow{6}{*}{$\begin{array}{l}\text { Public self-consciousness } \\
\text { (PUB) }\end{array}$} & PUB1 & I care about my lifestyle. \\
\hline & PUB2 & I am very interested in expressing myself. \\
\hline & PUB3 & I am highly aware of my appearance. \\
\hline & PUB4 & $\begin{array}{l}\text { I often worry about having to make a good impression of } \\
\text { myself. }\end{array}$ \\
\hline & PUB5 & $\begin{array}{l}\text { Before leaving the house, I check my appearance to see if I look } \\
\text { okay. }\end{array}$ \\
\hline & PUB6 & I care what people think about me. \\
\hline \multirow{6}{*}{$\begin{array}{l}\text { Social anxiety } \\
\text { (SOC) }\end{array}$} & SOC1 & It takes me time to overcome my shyness in new situations. \\
\hline & SOC2 & I find it hard to work if someone is watching me. \\
\hline & SOC3 & I am easily embarrassed. \\
\hline & SOC4 & I have no trouble talking to strangers. \\
\hline & SOC5 & I feel stressed when I have to speak in public. \\
\hline & SOC6 & Crowded places made me feel stressed. \\
\hline
\end{tabular}

Additionally, discriminant validity between constructs was ensured using cross-loading criteria of Fornell and Larcker (1981) and Chin (2010, 1998), shown in Appendix A (tables A1 and A2). The final measurement model indicates that photo manipulation leans towards correcting oneself (eliminating unwanted marks/characteristics, adjusting face/body shape and size) rather than decorating photos 
(adding additional stickers/emoticons, changing skin and picture colour). Also, body image esteem reflects a negative attitude towards one's body image as all the positive items such as weight and outer look satisfaction (perceived in both one's own and other people's view) were dropped. This is similar for social anxiety, where the only positive indicator on socialising ("It's easy for me to talk to strangers") also has the lowest loading value. For private self-consciousness, abstract items such as "I never take a hard look at myself" and "I know the way my mind works when I work through a problem" do not fit in the scale.

\subsection{Structural model}

The structural model has an acceptable goodness of fit (SMSR score) of 0.073 (Henseler et al., 2014). The hypothesis was tested using the path coefficient value from bootstrap with 5000 samples at the $5 \%$ significance level (Hair et al., 2011). Appendix B displays the results for the coefficient ( $\beta$ ) value, path coefficient (p) value and effect size $\left(\mathrm{f}^{2}\right)$. At the $5 \%$ significance level, if the $t$-value exceeds 1.96 and $p<0.05$, the structural parameter is considered significant (Hair et al., 2011). Therefore, all relationships in the structural model are supported except private self-consciousness -> perceived importance of self-photo manipulation $(p=0.236)$, and social anxiety $\rightarrow 3$ dependent variables $(p=0.325,0.615,0.857$ respectively).

The effect of relationship from perceived importance of self-photo manipulation to extent of self-photo manipulation and frequency of self-photo manipulation is moderate and large respectively; all other effects are weak according to Cohen's (1998) criteria. This is further illustrated using the $r^{2}$ value (Figure 1) where perceived importance of self-photo manipulation accounts for most of the variance in frequency of self-photo manipulation (63.7\%) and extent of self-photo manipulation (43.5\%). Body image esteem has 3 negative $\beta$ values. This suggests that a person with a higher body image esteem will not consider editing a photo of oneself important and subsequently will modify their photo less often with fewer changes. The negative path coefficient between private self-consciousness to extent and self-photo manipulation indicates that individuals with higher self-consciousness will be less likely to tamper with photos of themselves.

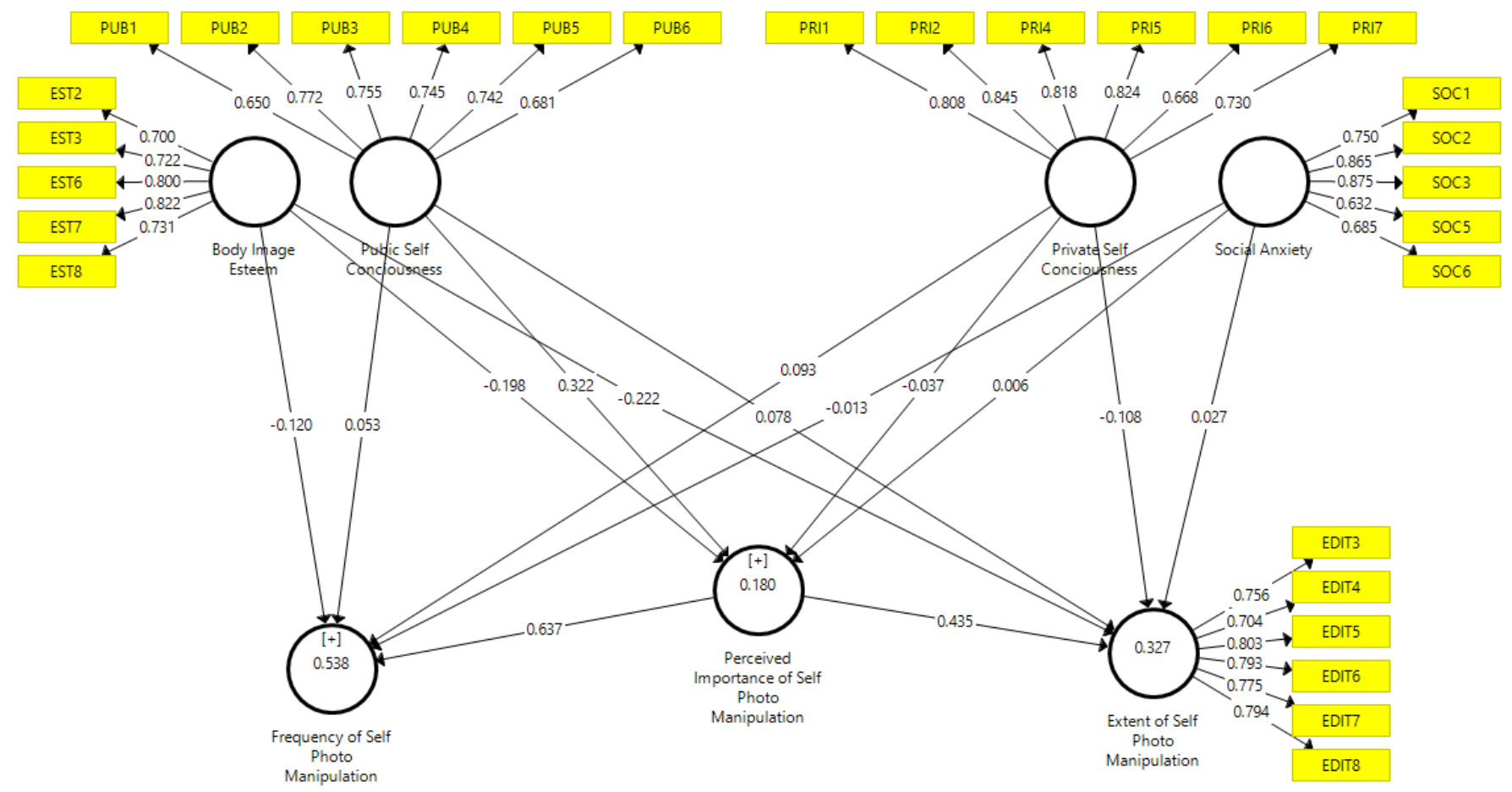

Figure 1. Endogenous latent constructs and outer loadings. 
Table 3. Structural model hypothesis and relationship testing.

\begin{tabular}{|c|c|c|c|c|c|c|}
\hline Hypothesis & Research construct & $\begin{array}{l}\text { Path } \\
\text { coefficients }\end{array}$ & t-value & p-values & $\mathbf{f}^{2}$ value & Supported \\
\hline $\mathrm{H} 1$ & $\begin{array}{l}\text { Body image esteem -> perceived } \\
\text { importance of self-photo } \\
\text { manipulation }\end{array}$ & -0.198 & 6.549 & 0 & 0.037 & Yes \\
\hline $\mathrm{H} 2$ & $\begin{array}{l}\text { Body image esteem -> extent of } \\
\text { self-photo manipulation }\end{array}$ & -0.222 & 7.341 & 0 & 0.055 & Yes \\
\hline H3 & $\begin{array}{l}\text { Body image esteem -> frequency } \\
\text { of self-photo manipulation }\end{array}$ & -0.12 & 4.516 & 0 & 0.023 & Yes \\
\hline $\mathrm{H} 4$ & $\begin{array}{l}\text { Perceived importance of self- } \\
\text { photo manipulation -> extent of } \\
\text { self-photo manipulation }\end{array}$ & 0.435 & 18.393 & 0 & 0.231 & Yes \\
\hline H5 & $\begin{array}{l}\text { Perceived importance of self- } \\
\text { photo manipulation -> } \\
\text { frequency of self-photo } \\
\text { manipulation }\end{array}$ & 0.637 & 30.425 & 0 & 0.722 & Yes \\
\hline H6 & $\begin{array}{l}\text { Private self-consciousness -> } \\
\text { extent of self-photo } \\
\text { manipulation }\end{array}$ & -0.108 & 3.705 & 0 & 0.012 & Yes \\
\hline $\mathrm{H} 7$ & $\begin{array}{l}\text { Private self-consciousness -> } \\
\text { frequency of self-photo } \\
\text { manipulation }\end{array}$ & 0.093 & 3.889 & 0 & 0.013 & Yes \\
\hline H8 & $\begin{array}{l}\text { Private self-consciousness -> } \\
\text { perceived importance of self- } \\
\text { photo manipulation }\end{array}$ & -0.037 & 1.185 & 0.236 & 0.001 & No \\
\hline H9 & $\begin{array}{l}\text { Public self-consciousness -> } \\
\text { extent of self-photo } \\
\text { manipulation }\end{array}$ & 0.078 & 2.536 & 0.011 & 0.005 & Yes \\
\hline $\mathrm{H} 10$ & $\begin{array}{l}\text { Public self-consciousness -> } \\
\text { frequency of self-photo } \\
\text { manipulation }\end{array}$ & 0.053 & 2.153 & 0.031 & 0.004 & Yes \\
\hline H11 & $\begin{array}{l}\text { Public self-consciousness -> } \\
\text { perceived importance of self- } \\
\text { photo manipulation }\end{array}$ & 0.322 & 9.313 & 0 & 0.081 & Yes \\
\hline $\mathrm{H} 12$ & $\begin{array}{l}\text { Social anxiety -> extent of self- } \\
\text { photo manipulation }\end{array}$ & 0.027 & 0.985 & 0.325 & 0.001 & No \\
\hline $\mathrm{H} 13$ & $\begin{array}{l}\text { Social anxiety }->\text { frequency of } \\
\text { self-photo manipulation }\end{array}$ & -0.013 & 0.503 & 0.615 & 0 & No \\
\hline H14 & $\begin{array}{l}\text { Social anxiety -> perceived } \\
\text { importance of self-photo } \\
\text { manipulation }\end{array}$ & 0.006 & 0.18 & 0.857 & 0 & No \\
\hline
\end{tabular}




\section{Discussion and Conclusions}

The objective of this research was to investigate the correlation between editing of social networking selfphotographs and the intention to change real-life appearance with the presence of image esteem as the mediator and was moderated by private self-consciousness. The results generally supported the theory in terms of the mediating relationship between the level of editing self-photos, self-esteem and private selfconsciousness. The moderating effect of private self-consciousness is not, however, supported. Our analysis also found additional direct relationships, for instance, a positive relationship between private self-consciousness and body image.

The findings reveal that female social media users who heavily edit their self-photos before posting them on Facebook commonly report low body image. This finding was consistent with previous studies in which greater use of self-image manipulation has been found to be related to higher body concerns. However, with three distinct alternative choices of action, the overall mediating relationship varied in outcomes: there were connections if the projected outcomes were intended to change by going to the gym, dieting, cosmetic surgery but not when it was intended to continue editing before posting on Facebook. These findings can be interpreted such that people having a high level of editing self-images and feeling insecure about their body image would want to change their flaws by committing to physical training, dieting, etc., or cosmetic surgery. The act of editing self-images therefore seems to be a trial by means of which people can have a look at what it would be like if they could change their appearance in accordance with their liking and then actually do something to change their real-life appearance instead of sticking with the act of curating their virtual self. However, the moderating effect of private self-consciousness was nowhere to be found.

It is noteworthy that there was a direct association between people who edit their self-images and intention to continue curating the virtual self and changing offline appearance. This direct relationship can be interpreted to mean that people who edit pictures but do not have body image concerns would still edit their pictures. Young adults with a high level of editing self-images might have a low body image, thus have a high intention of changing their actual appearance. There is also a positive relationship whereby people who curate their images severely but do not have low body image might continue doing so. The interpretations of findings outlined above are consistent with those of previous papers by McLean et al. (2015), Chen et al. (2019), Chae (2017), etc.

People altering pictures of themselves are frequently reported to have greater body-related and eating concerns (McLean et al., 2015) and increased consideration of surgery (Chen et al., 2019). Therefore, they enhance theirs picture before using them to perform self-expression and seek validation from others according to the explained motivations of sharing pictures on SNS. Particularly, sharing pictures of one's own appearance is considered an act of self-expression and seeking validation from others (Bazarova and Choi, 2014) through testaments (e.g., likes, comments) on SNS. Therefore, individuals might have the intention of altering their appearance in pictures to create a desired impression and gain approval from friends.

\section{Additional Information and Declarations}

Funding: This work was supported NAFOSTED Vietnam - The National Foundation for Science and Technology Development affiliated with the Ministry of Science and Technology (MOST) as a legal entity.

Conflict of Interests: The authors declare no conflict of interest.

Author Contributions: H.C.P.: Conceptualization, Supervision, Writing - original draft. L.N: Methodology, Data curation, Writing - original draft. T.A.V: Writing - review \& editing. P.T: Data curation, Software, Validation. 
Data Availability: The data that support the findings of this study are available from the corresponding author.

\section{Appendix A}

Table A1. Reliability and validity results after adjusting measurement scale.

\begin{tabular}{|c|c|c|c|c|c|c|}
\hline $\begin{array}{l}\text { Research } \\
\text { construct }\end{array}$ & Items & Loading & Cronbach's alpha & rho_A & Composite reliability & $\begin{array}{l}\text { Average } \\
\text { variance } \\
\text { extracted } \\
\text { (AVE) }\end{array}$ \\
\hline $\begin{array}{l}\text { Perceived } \\
\text { importance of self- } \\
\text { photo } \\
\text { manipulation }\end{array}$ & EDIT_IMP & 1 & 1 & 1 & 1 & 1 \\
\hline $\begin{array}{l}\text { Frequency of } \\
\text { editing photos }\end{array}$ & EDIT1 & 1 & 1 & 1 & 1 & 1 \\
\hline \multirow{6}{*}{$\begin{array}{l}\text { Extent of self- } \\
\text { photo } \\
\text { manipulation }\end{array}$} & EDIT3 & 0.756 & 0.864 & 0.866 & 0.898 & 0.596 \\
\hline & EDIT4 & 0.704 & & & & \\
\hline & EDIT5 & 0.803 & & & & \\
\hline & EDIT6 & 0.793 & & & & \\
\hline & EDIT7 & 0.775 & & & & \\
\hline & EDIT8 & 0.794 & & & & \\
\hline \multirow[t]{5}{*}{$\begin{array}{l}\text { Body image } \\
\text { esteem }\end{array}$} & EST2 & 0.7 & 0.813 & 0.825 & 0.869 & 0.572 \\
\hline & EST3 & 0.722 & & & & \\
\hline & EST6 & 0.8 & & & & \\
\hline & EST7 & 0.822 & & & & \\
\hline & EST8 & 0.731 & & & & \\
\hline \multirow[t]{6}{*}{$\begin{array}{l}\text { Private self- } \\
\text { consciousness }\end{array}$} & PRI1 & 0.808 & 0.877 & 0.895 & 0.905 & 0.616 \\
\hline & PRI2 & 0.845 & & & & \\
\hline & PRI4 & 0.818 & & & & \\
\hline & PRI5 & 0.824 & & & & \\
\hline & PRI6 & 0.668 & & & & \\
\hline & PRI7 & 0.73 & & & & \\
\hline \multirow[t]{6}{*}{$\begin{array}{l}\text { Public self- } \\
\text { consciousness }\end{array}$} & PUB1 & 0.65 & 0.82 & 0.827 & 0.869 & 0.526 \\
\hline & PUB2 & 0.772 & & & & \\
\hline & PUB3 & 0.755 & & & & \\
\hline & PUB4 & 0.745 & & & & \\
\hline & PUB5 & 0.742 & & & & \\
\hline & PUB6 & 0.681 & & & & \\
\hline
\end{tabular}




\begin{tabular}{|l|l|r|r|r|r|l|}
\hline $\begin{array}{l}\text { Research } \\
\text { construct }\end{array}$ & Items & Loading & Cronbach's alpha & rho_A & Composite reliability & $\begin{array}{l}\text { Average } \\
\text { variance } \\
\text { extracted } \\
\text { (AVE) }\end{array}$ \\
\hline \multirow{3}{*}{ Social anxiety } & SOC1 & 0.75 & 0.835 & 0.927 & 0.876 & 0.589 \\
\cline { 2 - 8 } & SOC2 & 0.865 & & & & \\
\cline { 2 - 8 } & SOC3 & 0.875 & & & & \\
\cline { 2 - 8 } & SOC5 & 0.632 & & & & \\
\cline { 2 - 8 } & SOC6 & 0.685 & & & & \\
\hline
\end{tabular}

Table A2. Discriminant validity - Fornell-Larcker criterion.

\begin{tabular}{|c|c|c|c|c|c|c|c|}
\hline $\begin{array}{l}\text { Research } \\
\text { construct }\end{array}$ & $\begin{array}{l}\text { Body } \\
\text { image } \\
\text { esteem }\end{array}$ & $\begin{array}{l}\text { Extent of } \\
\text { self-photo } \\
\text { manipulati } \\
\text { on }\end{array}$ & $\begin{array}{l}\text { Frequency of } \\
\text { self-photo } \\
\text { manipulation }\end{array}$ & $\begin{array}{l}\text { Perceived } \\
\text { importance of } \\
\text { self-photo } \\
\text { manipulation }\end{array}$ & $\begin{array}{l}\text { Private self- } \\
\text { consciousness }\end{array}$ & $\begin{array}{l}\text { Public } \\
\text { self- } \\
\text { consciousn } \\
\text { ess }\end{array}$ & $\begin{array}{l}\text { Social } \\
\text { anxiety }\end{array}$ \\
\hline $\begin{array}{l}\text { Body image } \\
\text { esteem }\end{array}$ & 0.756 & & & & & & \\
\hline $\begin{array}{l}\text { Extent of self- } \\
\text { photo } \\
\text { manipulation }\end{array}$ & -0.373 & 0.772 & & & & & \\
\hline $\begin{array}{l}\text { Frequency of } \\
\text { self-photo } \\
\text { manipulation }\end{array}$ & -0.36 & 0.519 & $1^{* *}$ & & & & \\
\hline $\begin{array}{l}\text { Perceived } \\
\text { importance of } \\
\text { self-photo } \\
\text { manipulation }\end{array}$ & -0.317 & 0.52 & 0.71 & $1^{* *}$ & & & \\
\hline $\begin{array}{l}\text { Private self- } \\
\text { consciousness }\end{array}$ & -0.25 & 0.075 & 0.264 & 0.184 & 0.785 & & \\
\hline $\begin{array}{l}\text { Public self- } \\
\text { consciousness }\end{array}$ & -0.39 & 0.282 & 0.387 & 0.382 & 0.526 & 0.725 & \\
\hline Social anxiety & -0.373 & 0.182 & 0.186 & 0.175 & 0.274 & 0.328 & 0.768 \\
\hline
\end{tabular}

Note: * The diagonals are the square roots of AVE and the off-diagonal values are the correlation between the latent constructs.

** Single-item construct. 


\section{Appendix B}

Table B1. Discriminant validity - cross-loading.

\begin{tabular}{|c|c|c|c|c|c|c|c|}
\hline $\begin{array}{l}\text { Research } \\
\text { construct }\end{array}$ & $\begin{array}{l}\text { Body } \\
\text { image } \\
\text { esteem }\end{array}$ & $\begin{array}{l}\text { Extent of } \\
\text { self-photo } \\
\text { manipulat } \\
\text { ion }\end{array}$ & $\begin{array}{l}\text { Frequency of } \\
\text { self-photo } \\
\text { manipulation }\end{array}$ & $\begin{array}{l}\text { Perceived } \\
\text { importance of } \\
\text { self-photo } \\
\text { manipulation }\end{array}$ & $\begin{array}{l}\text { Private self- } \\
\text { consciousness }\end{array}$ & $\begin{array}{l}\text { Public self- } \\
\text { consciousness }\end{array}$ & $\begin{array}{l}\text { Social } \\
\text { anxiety }\end{array}$ \\
\hline EDIT1 & -0.36 & 0.519 & 1 & 0.71 & 0.264 & 0.387 & 0.186 \\
\hline EDIT3 & -0.234 & 0.756 & 0.447 & 0.451 & 0.053 & 0.24 & 0.15 \\
\hline EDIT4 & -0.227 & 0.704 & 0.405 & 0.407 & 0.031 & 0.184 & 0.123 \\
\hline EDIT5 & -0.318 & 0.803 & 0.316 & 0.343 & 0.046 & 0.208 & 0.106 \\
\hline EDIT6 & -0.373 & 0.793 & 0.459 & 0.432 & 0.089 & 0.231 & 0.176 \\
\hline EDIT7 & -0.254 & 0.775 & 0.397 & 0.402 & 0.051 & 0.231 & 0.155 \\
\hline EDIT8 & -0.312 & 0.794 & 0.357 & 0.354 & 0.074 & 0.207 & 0.123 \\
\hline EDIT_IMP & -0.317 & 0.52 & 0.71 & 1 & 0.184 & 0.382 & 0.175 \\
\hline EST2 & 0.7 & -0.209 & -0.237 & -0.188 & -0.189 & -0.288 & -0.23 \\
\hline EST3 & 0.722 & -0.357 & -0.213 & -0.222 & -0.118 & -0.247 & -0.203 \\
\hline EST6 & 0.8 & -0.3 & -0.355 & -0.289 & -0.27 & -0.405 & -0.317 \\
\hline EST7 & 0.822 & -0.275 & -0.301 & -0.278 & -0.207 & -0.306 & -0.314 \\
\hline EST8 & 0.731 & -0.256 & -0.235 & -0.2 & -0.144 & -0.203 & -0.342 \\
\hline PRI1 & -0.173 & 0.043 & 0.24 & 0.154 & 0.808 & 0.468 & 0.206 \\
\hline PRI2 & -0.283 & 0.071 & 0.253 & 0.166 & 0.845 & 0.496 & 0.292 \\
\hline PRI4 & -0.24 & 0.049 & 0.211 & 0.14 & 0.818 & 0.4 & 0.26 \\
\hline PRI5 & -0.239 & 0.067 & 0.225 & 0.16 & 0.824 & 0.408 & 0.251 \\
\hline PRI6 & -0.061 & 0.06 & 0.085 & 0.078 & 0.668 & 0.285 & 0.106 \\
\hline PRI7 & -0.097 & 0.07 & 0.166 & 0.139 & 0.73 & 0.363 & 0.105 \\
\hline PUB1 & -0.129 & 0.096 & 0.204 & 0.197 & 0.496 & 0.65 & 0.149 \\
\hline PUB2 & -0.237 & 0.278 & 0.289 & 0.312 & 0.371 & 0.772 & 0.103 \\
\hline PUB3 & -0.216 & 0.193 & 0.277 & 0.295 & 0.38 & 0.755 & 0.135 \\
\hline PUB4 & -0.393 & 0.254 & 0.267 & 0.279 & 0.314 & 0.745 & 0.373 \\
\hline PUB5 & -0.285 & 0.15 & 0.327 & 0.274 & 0.441 & 0.742 & 0.249 \\
\hline PUB6 & -0.394 & 0.216 & 0.304 & 0.281 & 0.343 & 0.681 & 0.404 \\
\hline SOC1 & -0.225 & 0.098 & 0.078 & 0.096 & 0.172 & 0.241 & 0.75 \\
\hline SOC2 & -0.342 & 0.173 & 0.226 & 0.188 & 0.298 & 0.337 & 0.865 \\
\hline SOC3 & -0.373 & 0.146 & 0.211 & 0.163 & 0.258 & 0.282 & 0.875 \\
\hline SOC5 & -0.141 & 0.136 & -0.002 & 0.065 & 0.065 & 0.162 & 0.632 \\
\hline SOC6 & -0.247 & 0.139 & 0.045 & 0.09 & 0.132 & 0.16 & 0.685 \\
\hline
\end{tabular}

Note: Loading of all items is highest on the constructs they are intended to measure. 


\section{References}

Abraham, C., Sheeran, P., \& Johnston, M. (1998). From health beliefs to self-regulation: Theoretical advances in the psychology of action control. Psychology \& Health, 13(4), 569-591. https://doi.org/10.1080/08870449808407420

Ajzen, I. (2011). The theory of planned behaviour: Reactions and reflections. Psychology \& Health, 26(9), $1113-1127$. https://doi.org/10.1080/08870446.2011.613995

Baym, N. K. (1998). The Emergence of On-Line Community. In Cybersociety 2.0: Revisiting Computer-Mediated Communication and Community, (pp. 35-68). Sage. https://doi.org/10.4135/9781452243689.n2

Bazarova, N. N., \& Choi, Y. H. (2014). Self-Disclosure in Social Media: Extending the Functional Approach to Disclosure Motivations and Characteristics on Social Network Sites. Journal of Communication, 64(4), 635-657. https://doi.org/10.1111/jcom.12106

Behm-Morawitz, E. (2013). Mirrored selves: The influence of self-presence in a virtual world on health, appearance, and wellbeing. Computers in Human Behavior, 29(1), 119-128. https://doi.org/10.1016/j.chb.2012.07.023

Boyd, D. (2010). Making Sense of Privacy and Publicity. https://www.danah.org/papers/talks/2010/SXSW2010.html

Boyd, D. M., \& Ellison, N. B. (2007). Social Network Sites: Definition, History, and Scholarship. Journal of Computer-Mediated Communication, 13(1), 210-230. https://doi.org/10.1111/j.1083-6101.2007.00393.x

Bullingham, L., \& Vasconcelos, A. C. (2013). "The presentation of self in the online world": Goffman and the study of online identities. Journal of Information Science, 39(1), 101-112. https://doi.org/10.1177/0165551512470051

Chae, J. (2017). Virtual makeover: Selfie-taking and social media use increase selfie-editing frequency through social comparison. Computers in Human Behavior, 66, 370-376. https://doi.org/10.1016/j.chb.2016.10.007

Chen, J., Ishii, M., Bater, K. L., Darrach, H., Liao, D., Huynh, P. P., Reh, I. P., Nellis, J. C., Kumar, A. R., \& Ishii, L. E. (2019). Association Between the Use of Social Media and Photograph Editing Applications, Self-esteem, and Cosmetic Surgery Acceptance. JAMA Facial Plastic Surgery, 21(5), 361. https://doi.org/10.1001/jamafacial.2019.0328

Chin, W. W. (2010). How to write up and report PLS analyses. In V. Esposito, W. W. Chin, H. Henseler, and H. Wang, Handbook of partial least squares: concepts, methods and applications in marketing and related fields (pp. 655-690). Springer. https://doi.org/10.1007/978-3-540-32827-8 29

Chin, W. W. (1998). The partial least squares approach for structural equation modeling. In G. A. Marcoulides, Modern methods for business research (pp. 295-336). Lawrence Erlbaum.

Cohen, J. E. (1998). Statistical Power Analysis for the Behavioral Sciences. Lawrence Erlbaum.

Cohen, R., Newton-John, T., \& Slater, A. (2018). "Selfie"-objectification: The role of selfies in self-objectification and disordered eating in young women. Computers in Human Behavior, 79, 68-74. https://doi.org/10.1016/j.chb.2017.10.027

Dobson, A. S. (2016). Postfeminist Digital Cultures: Femininity, Social Media, and Self-Representation. Palgrave Macmillan.

Elias, N., \& Lemish, D. (2009). Spinning the web of identity: the roles of the internet in the lives of immigrant adolescents. New Media \& Society, 11(4), 533-551. https://doi.org/10.1177/1461444809102959

Fardouly, J., Diedrichs, P. C., Vartanian, L. R., \& Halliwell, E. (2015). Social comparisons on social media: The impact of Facebook on young women's body image concerns and mood. Body Image, 13(1), 38-45. https://doi.org/10.1016/j.bodyim.2014.12.002

Ferguson, C. J. (2009). An effect size primer: A guide for clinicians and researchers. Professional Psychology: Research and Practice, 40(5), 532-538. https://doi.org/10.1037/a0015808

Fishbein, M., \& Ajzen, I. (1980). Understanding attitudes and predicting social behaviour. Prentice Hall.

Fornell, C., \& Larcker, D. F. (1981). Evaluating Structural Equation Models with Unobservable Variables and Measurement Error. Journal of Marketing Research, 18(1), 39-50. https://doi.org/10.2307/3151312

Fox, J., \& Rooney, M. C. (2015). The Dark Triad and trait self-objectification as predictors of men's use and self-presentation behaviors on social networking sites. Personality and Individual Differences, 76, 161-165. https://doi.org/10.1016/j.paid.2014.12.017

Fox, J., \& Vendemia, M. A. (2016). Selective Self-Presentation and Social Comparison Through Photographs on Social Networking Sites. Cyberpsychology, Behavior, and Social Networking, 19(10), 593-600. https://doi.org/10.1089/cyber.2016.0248

Goffman, E. (1959). The Presentation of Self in Everyday Life. Doubleday.

Grisso, A. D., \& Weiss, D. (2005) 'What Are Gurls Talking About? Adolescent girls' Construction of Sexual Identity on Gurl.Com'. In Sharon. R. Mazzarella (ed.) Girl Wide Web. Girls, the Internet, and the Negotiation of Identity, (pp. 31-50). Peter Lang.

Hair, J. F., Hult, G. T., Ringle, C. M., \& Sarstedt, M. (2017). A Primer on Partial Least Squares Structural Equation Modeling (PLS-SEM). Sage Publications.

Hair, J. F., Ringle, C. M., \& Sarstedt, M. (2011). PLS-SEM: Indeed a Silver Bullet. Journal of Marketing Theory and Practice, 19(2), 139-152. https://doi.org/10.2753/mtp1069-6679190202

Halpern, D., Katz, J. E., \& Carril, C. (2017). The online ideal persona vs. the jealousy effect: Two explanations of why selfies are associated with lower-quality romantic relationships. Telematics and Informatics, 34(1), 114-123. https://doi.org/10.1016/j.tele.2016.04.014 
Henseler, J., Dijkstra, T. K., Sarstedt, M., Ringle, C. M., Diamantopoulos, A., Straub, D. W., Ketchen, D. J., Hair, J. F., Hult, G. T. M., \& Calantone, R. J. (2014). Common Beliefs and Reality About PLS. Organizational Research Methods, 17(2), 182-209. https://doi.org/10.1177/1094428114526928

Herring, S. C., Scheidt, L. A., Bonus, S., \& Wright, E. (2004). Bridging the gap: a genre analysis of Weblogs. In Proceedings of the 37th Annual Hawaii International Conference on System Sciences, 2004. IEEE. https://doi.org/10.1109/hicss.2004.1265271

Hill, K., Bennett, P., \& Hunter, R. (2021). "It's social interaction... but it's not": A qualitative study investigating the psychosocial experience of social media by individuals with a visual impairment. Journal of Health Psychology, (in press), 1-14. https://doi.org/10.1177/1359105321995949

Krizan, Z., \& Bushman, B. J. (2011). Better than my loved ones: Social comparison tendencies among narcissists. Personality and Individual Differences, 50(2), 212-216. https://doi.org/10.1016/j.paid.2010.09.031

Kuhl, J., \& Fuhrmann, A. (1998). Decomposing self-regulation and self-control: The volitional components checklist. In J. Heckhausen, and C. Dweck, Life-span perspective on motivation and control (pp. 19-45). Erlbaum.

Lamp, S. J., Cugle, A., Silverman, A. L., Thomas, M. T., Liss, M., \& Erchull, M. J. (2019). Picture Perfect: The Relationship between Selfie Behaviors, Self-Objectification, and Depressive Symptoms. Sex Roles, 81, 704-712. https://doi.org/10.1007/s11199-019-01025-z

Lee, J. K. (2020). The effects of social comparison orientation on psychological well-being in social networking sites: Serial mediation of perceived social support and self-esteem. Current Psychology, (in press), 1-13. https://doi.org/10.1007/s12144-020-01114-3

Leontiev, A. N. (1978). Activity, consciousness, and personality. Prentice Hall.

Leontiev, A. N. (1981). Problems of the development of the mind. Progress.

Lonergan, A. R., Bussey, K., Mond, J., Brown, O., Griffiths, S., Murray, S. B., \& Mitchison, D. (2019). Me, my selfie, and I: The relationship between editing and posting selfies and body dissatisfaction in men and women. Body Image, 28, 39-43. https://doi.org/10.1016/j.bodyim.2018.12.001

Lowe-Calverley, E., \& Grieve, R. (2018). Self-ie love: Predictors of image editing intentions on Facebook. Telematics and Informatics, 35(1), 186-194. https://doi.org/10.1016/j.tele.2017.10.011

Maddux, J. E. (1993). Social cognitive models of health and exercise behavior: An introduction and review of conceptual issues. Journal of Applied Sport Psychology, 5(2), 116-140. https://doi.org/10.1080/10413209308411310

Maddux, J. E., \& Rogers, R. W. (1983). Protection motivation and self-efficacy: A revised theory of fear appeals and attitude change. Journal of Experimental Social Psychology, 19(5), 469-479. https://doi.org/10.1016/0022-1031(83)90023-9

McEachan, R. R. C., Conner, M., Taylor, N. J., \& Lawton, R. J. (2011). Prospective prediction of health-related behaviours with the Theory of Planned Behaviour: a meta-analysis. Health Psychology Review, 5(2), 97-144. https://doi.org/10.1080/17437199.2010.521684

McLean, S. A., Paxton, S. J., Wertheim, E. H., \& Masters, J. (2015). Photoshopping the selfie: Self photo editing and photo investment are associated with body dissatisfaction in adolescent girls. International Journal of Eating Disorders, 48(8), 1132-1140. https://doi.org/10.1002/eat.22449

Meier, E. P., \& Gray, J. (2014). Facebook Photo Activity Associated with Body Image Disturbance in Adolescent Girls. Cyberpsychology, Behavior, and Social Networking, 17(4), 199-206. https://doi.org/10.1089/cyber.2013.0305

Mendelson, B. K., Mendelson, M. J., \& White, D. R. (2001). Body-Esteem Scale for Adolescents and Adults. Journal of Personality Assessment, 76(1), 90-106. https://doi.org/10.1207/s15327752jpa7601 6

Mills, J. S., Musto, S., Williams, L., \& Tiggemann, M. (2018). "Selfie" harm: Effects on mood and body image in young women. Body Image, 27, 86-92. https://doi.org/10.1016/j.bodyim.2018.08.007

Milne, S., Orbell, S., \& Sheeran, P. (2002). Combining motivational and volitional interventions to promote exercise participation: Protection motivation theory and implementation intentions. British Journal of Health Psychology, 7(2), 163184. https://doi.org/10.1348/135910702169420

Nguyen, T.-N., McDonald, M., Nguyen, T. H. T., \& McCauley, B. (2020). Gender relations and social media: a grounded theory inquiry of young Vietnamese women's self-presentations on Facebook. Gender, Technology and Development, 24(2), 174-193. https://doi.org/10.1080/09718524.2020.1719598

Orbell, S. (2003). Personality systems interactions theory and the theory of planned behaviour: Evidence that self-regulatory volitional components enhance enactment of studying behaviour. British Journal of Social Psychology, 42(1), 95-112. https://doi.org/10.1348/014466603763276144

Orbell, S., \& Sheeran, P. (1998). "Inclined abstainers": A problem for predicting health-related behaviour. British Journal of Social Psychology, 37(2), 151-165. https://doi.org/10.1111/j.2044-8309.1998.tb01162.x

Orbell, S., Hodgkins, S., \& Sheeran, P. (1997). Implementation Intentions and the Theory of Planned Behavior. Personality and Social Psychology Bulletin, 23(9), 945-954. https://doi.org/10.1177/0146167297239004

Pacherie, E. (2006). Toward a Dynamic Theory of Intentions. In S. Pockett, W. P. Banks, and S. Gallagher, Does consciousness cause behaviour (pp. 145-167). MIT Press.

Prochaska, J. O., \& DiClemente, C. C. (1983). Stages and processes of self-change of smoking: Toward an integrative model of change. Journal of Consulting and Clinical Psychology, 51(3), 390-395. https://doi.org/10.1037/0022-006x.51.3.390 
Rhodes, R. E., \& de Bruijn, G.-J. (2013). How big is the physical activity intention-behaviour gap? A meta-analysis using the action control framework. British Journal of Health Psychology, 18(2), 296-309. https://doi.org/10.1111/bjhp.12032

Scheier, M. F., \& Carver, C. S. (1988). A Model of Behavioral Self-Regulation: Translating Intention into Action. Advances in Experimental Social Psychology, 303-346. https://doi.org/10.1016/s0065-2601(08)60230-0

Scheier, M. F., \& Carver, C. S. (1985). The Self-Consciousness Scale: A Revised Version for Use with General Populations1. Journal of Applied Social Psychology, 15(8), 687-699. https://doi.org/10.1111/j.1559-1816.1985.tb02268.x

Searle, J. (1981). The intentionality of intention and action. Cognitive Science, 4(1), 47-70. https://doi.org/10.1016/s0364$\underline{0213(81) 80004-3}$

Sheeran, P. (2002). Intention-Behavior Relations: A Conceptual and Empirical Review. European Review of Social Psychology, 12(1), 1-36. https://doi.org/10.1080/14792772143000003

Shukla, U. (2017). Selling skinny: Marketing, social media and female body image. University of Texas.

Sniehotta, F. F., Scholz, U., \& Schwarzer, R. (2005). Bridging the intention-behaviour gap: Planning, self-efficacy, and action control in the adoption and maintenance of physical exercise. Psychology \& Health, 20(2), 143-160. https://doi.org/10.1080/08870440512331317670

Stevens, J. P. (2002). Applied multivariate statistics for the social sciences. Lawrence Erlbaum.

Sunden, J. (2003). Material Virtualities: Approaching Online Textual Embodiment. Peter Lang.

Tamborini, R., \& Skalski, P. (2006). The role of presence in the experience of electronic games. In P. Vorderer, and J. Bryant, Playing video games: Motivations, responses and consequences (pp. 227-228). Lawrence Earlbaun Associates.

Thompson, J. K., Heinberg, L. J., Altabe, M., \& Tantleff-Dunn, S. (1999). Exacting beauty: Theory, assessment, and treatment of body image disturbance. American Psychological Association. https://doi.org/10.1037/10312-000

Thumim, N. (2012). Self-representation and digital culture. New York.

Tiggemann, M., \& Miller, J. (2010). The Internet and Adolescent Girls' Weight Satisfaction and Drive for Thinness. Sex Roles, 63(1-2), 79-90. https://doi.org/10.1007/s11199-010-9789-z

Tiggemann, M., \& Slater, A. (2013). NetGirls: The Internet, Facebook, and body image concern in adolescent girls. International Journal of Eating Disorders, 46(6), 630-633. https://doi.org/10.1002/eat.22141

Vasalou, A., \& Joinson, A. N. (2009). Me, myself and I: The role of interactional context on self-presentation through avatars. Computers in Human Behavior, 25(2), 510-520. https://doi.org/10.1016/j.chb.2008.11.007

Vendemia, M. A., \& DeAndrea, D. C. (2018). The effects of viewing thin, sexualized selfies on Instagram: Investigating the role of image source and awareness of photo editing practices. Body Image, 27, 118-127. https://doi.org/10.1016/j.bodyim.2018.08.013

Wertheim, E. H., \& Paxton, S. J. (2012). Body image development-Adolescent girls. In Encyclopaedia of Body Image and Human Appearance (pp. 187-193). Elsevier Press.

Westlake, E. J. (2008). Friend me if you Facebook: Generation Y and performative surveillance. The Drama Review, 52(4), 2140. https://doi.org/10.1162/dram.2008.52.4.21

Editorial record: The article has been peer-reviewed. First submission received on 24 August 2021. Revisions received on 7 September 2021, and 7 November 2021. Accepted for publication on 27 November 2021. The editor in charge of coordinating the peer-review of this manuscript and approving it for publication was Zdenek Smutny (D).

Acta Informatica Pragensia is published by Prague University of Economics and Business, Czech Republic.

ISSN: 1805-4951 